\title{
Ibadan Slaves and Ibadan Wars in Pre-Colonial South Western Nigeria, 1835-1893
}

\author{
${ }^{1}$ Salami, ${ }^{2}$ B. Olawale \\ ${ }^{1,2}$ Department of History and Diplomatic Studies Olabisi Onabanjo University, Ago-Iwoye, Ogun State Nigeria
}

\begin{abstract}
The history of nations, right from the period of evolution through the middle ages and the modern world, has been fraught with one form of interaction or another. Such interactions may come in form of war, politics, economic or culture. In the process of interaction in the life of such nations, security concerns are always very important either to protect its citizens internally or to defend its geographical space or both. This concern for security propels nations into developing military means, such as that of Hitler's Germany and Mussolini's Italy. Therefore, the love for security and expansion compel nations to embrace militarism. In other words, militarism is seen as a significant element in the preservation of a nation's territorial boundary and imperialist expansion. The Ibadan of our period replicated our ongoing analysis. In this regard, this paper takes a look at the predominance of militarism in the pre-colonial Ibadan society and how the military class exalted military virtues and ideals above all other means to build a society that served the needs of their time.
\end{abstract}

Key Words: Slaves, Wars, Ibadan, Pre-Colonial, Nigeria

\section{Introduction}

Ibadan is a Yoruba town in the South-western part of Nigeria. The city emerged as a by-product of the early nineteenth century political crisis in Yorubaland. The political upheavals in Yorubaland during that period were fraught with serious consequences which are still militating against the unity of the Yoruba race. Ibadan held sway as a force to be reckoned with in Yorubaland since its foundation in 1829 to the period when colonial rule was established in Yorubaland about 1893. It fought several wars to establish itself and maintain the independence of the Yoruba race from the Fulani jihadist that ravaged northern part of Yorubaland in the nineteenth century. The focus of this paper is the role of slaves in the execution of war in Yorubaland in the nineteenth century with particular emphasis on Ibadan.

Copious study on the history of the Yoruba people and Ibadan most especially has enriched our understanding of the history of the town. Nevertheless, the role of slaves in the socio-economic and political life of Ibadan has received scanty attention from scholars and historians in particular. To start with, Reverend Samuel Johnson did an elaborate study on the Yoruba people [25]. Johnson categorised by O. Omosini as an amateur, non-professional historiographer in the ilk of Reverend C.C Reindorf of Ghana gave useful insight into the foundation and growth of Ibadan as a Yoruba city state in the nineteenth century [23]. In his general discussion of the various wars that Ibadan fought during this period however, Johnson paid no attention to the roles that slave played in the socio-economic and political life of Ibadan.

Similarly, Bolanle Awe, Toyin Falola and a number of modern academic historians have also contributed meaningfully to the study of the history of Ibadan. Awe in her Ph.D Thesis for instance, discussed the development of Ibadan from a war camp into a formidable empire in Yorubaland in the nineteenth century [6]. Not far from this, S. A. Akintoye examined the imperial activities of Ibadan in eastern Yorubaland [4]. Akintoye examines the success and failure of Ibadan more importantly during this period. Nevertheless, the role of slaves in Ibadan received very scanty attention. Toyin Falola however, did a study on the political economy of Ibadan between 1830 and 1900 [13]. Falola examines various aspects of Ibadan history but fail to examine in detail the slave factor in the military activities of Ibadan as an imperial city state in Yorubaland during the period under review.

From a different perspective however, Ruth Watson examines the historical relationship between the political institution of chieftaincy and civic pride in Ibadan. Watson's work explores how a 'civic Ibadan' was made through practices of settlement, civil disorder and external warfare during the pre-colonial period [31]. This obvious lack of interest by Yoruba historiographers gave rise to this study.

\section{The foundation and early history of Ibadan}

The ancient Ibadan settlements were peopled by a section of Egba Aguras, who were known as Ibadan Soge. The settlement lay between the Ijebu and Egba towns in the forest belt and Oyo in the Savannah belt. Ibadan was created in 1829 as a war camp for warriors coming from Oyo, Ife and Ijebu. The city is a forest site made up of several ranges of hills, varying in elevation from 160 to 275 meters [14]. The location of the town 
offered strategic defense opportunities. Moreover, its location at the fringe of the forest promoted its emergence as a marketing centre for traders and goods from both the forest and grassland areas. Ibadan thus began as a military state and remained so until the last decade of the 19th century. The city-state also succeeded in building a large empire from the 1860s to the 1890s and extended over much of northern and eastern Yorubaland. Ibadan was appropriately nicknamed idi Ibon, "butt of a gun", because of its unique military character. The warriors constituted the rulers of the city and the most important economic group (Falola, 1984: 192). However, the economy of Ibadan primarily rested on agriculture, manufacture and trade mainly in slaves, palm oil, yam, kola for export, shea butter, salt, horses, and weapons imported to the town from outside [14].

The settlements were principally occupied by fugitives, outlaws, rascals and criminals from the neighbouring towns and villages. They lived by plundering surrounding farms, villages and towns and were so daring that the inhabitants of the neighbouring villages regarded their settlements as a place of the lunatics. After some years, the wave of migrant ions sweeping through the northern part of Yorubaland, partly due to the dynastic struggles and the dislocation caused by the Fulani Jihadists who had made incursions into the north of Yoruba country, forced a lot of Yoruba groups and warriors to move to more relatively safe areas down south. Ibadan was one of those 'safe' areas that accommodated the migrants. Before long, the warrior migrants reorganised the settlement and developed it into a war camp. This gave it a unique opportunity among other Yoruba towns for developing a definite military propensity. The settlers, apart from taking up Yoruba traditional occupation of agriculture, were all potential soldiers. This became necessary because of the need to be in a state of military preparedness against the Fulani who had driven them out of their original homes. Quite a considerable number of able bodied freeborn, migrants and slaves were trained as soldiers by the Ologun. Each warrior chief had his own army consisting of quite a number of slaves and some members of his household. It was the responsibility of the military chief to train his soldiers in the art of military warfare, especially on 'tactics and strategy and the use of 'modern' weapons'[13].

The soldier-slaves were got mainly from the captives of war and partly from the slaves sent to Ibadan as tributes and gifts from the conquered towns. They were enrolled to serve in the armies of various Ologun since Ibadan as a state, had no standing army of its own. Thus the onus fell on the warrior chiefs along with their retainers to defend the territorial interest of the state. To that extent, each of the war-lords built his own private army and since the soldier-slaves were more important in a military state like Ibadan, their training was taken with all seriousness it deserved. They were deliberately trained in the methods of warfare, with emphasis on marksmanship, leadership, other military strategies and valour. They were ready to serve in as much as they were guaranteed shelter, food, clothing and weapons of war. Their impact was felt in foreign policy and diplomacy, in government and most importantly, at the battle field. They were part of the law enforcement agents, administrators, tax collectors and were creatures to be exchanged for weapons of war.

\section{The Military Means, the Wars and the captives}

The military prowess of Ibadan and the valour of its generals positioned the city-state as a force to be reckoned with in Yorubaland in the period under review. Bolanle Awe in her thesis Awe submitted that Ibadan was a "Republic of Warriors"[6]. In fact, the city owed its foundation and rise as an imperial power in Yorubaland during the early nineteenth century to its unrivalled military tradition among other Yoruba states. Oba Akinyele was apt to say that "in Ibadan, the leading enterprise was warfare; very few people were farmers, and the few were despised”. And to buttress this, Ruth Watson drew our attention to 'Ibadan City Anthem' as recited in Ibadan mementoes:

Ibadan, ilu jagunjagun

Awon to so o d'ilu nla

Awa omo re ko ni je

K'ola ti ogo won run

Ibadan, city of warriors

They who made it into a great city

We its children will not allow

That their honour and glory perish [31]

Apparently, an important aspect of Ibadan military tradition during our own time is the role of slaves in the execution of several activities in the city and more importantly war. The military leaders in Ibadan relied very much on the soldier-slaves for their wealth and power. The slaves apart from other functions they perform in the state, also featured prominently in all the wars fought by the Ibadan in an attempt to bring about balance of power in Yorubaland after the demise of the Old Oyo Empire. Each of the war-chiefs could put as much as one thousand soldier-slaves or more on the battle field at a time. For instance, during the Ijaiye war (18601862), Ogunmola, a notable Ibadan Ologun, put so many of his soldier-slaves on the battle field that between April 10, 1860, when the war commenced and March 17, 1862, when it ended, he had lost about one thousand and eight hundred of them. ${ }^{3}$ Women chiefs also had their own war-captains and war-boys who were slaves. 
Madam Efunsetan Aniwura had over two thousand slaves of which some were captains of war and war-boys excluding her domestic servants. ${ }^{4}$ In fact, when the Ijebu took the opportunity of Ibadan soldiers' exit from home to Ekiti country, to attack Ibadan, it was a woman, Madam Omosa, the only female child of Ogunmola, who organised her soldier-slaves to repel the attack and drove the Ijebu back as far as Mamu stream in Ijebuland [21].

Booties of movable goods like slaves, cloths, household utensils and live-stock were the by-products of wars. These constituted a form of capital accumulation which the professional soldiers needed to maintain and strengthen their military and political positions. The greater percentage of these booties belonged to the Ologun while the soldier-slaves had little. The Ologun on the other hand must give a quota of their booties to the Baale' and the Balogun. Every Ologun also received from his subordinates [13]. The soldier-slave, who was successful in war and caught several slaves, released them to his master. In most cases, some of their masters would return one or two fifths to the soldier-slaves. There were few cases of unkind masters who would keep all the booties, claiming that the service which the soldier-slave had rendered was his duty [25].

Furthermore, any of these soldier-slaves could buy his own freedom by giving his own share of the booties of war to his master in the presence of a witness. He was thus free to move around as a freeman and henceforth, he would serve as a free-soldier under his former master. Like the freeborn soldiers, he was expected to give to his warrior-chief one or two captives, depending on the number of captives he got from a particular expedition. But if he became idle and depended largely on his master for everything including his weapons of war and his debts, he was expected to give up more than a half or nearly all his booties of war [25]. There were highly placed soldier-slaves in Ibadan. Their masters put them in positions of trust and responsibility especially the courageous ones who must have proved themselves worthy of trust. These highly placed soldierslaves kept horses of their own, farms and farm-houses. They were responsible for the training of the young soldier-slaves and freeborn recruits. By all standards, the highly placed slaves were always richly dressed and were often seen on the streets than their masters. It is said that, whatever the misfortunes of the household, they were not to be sold. They were to remain guardians of the house and their masters' sons. Their children were regarded as home-born slaves and could not easily be distinguished from the freeborn children [25]. The more of these highly placed soldier-slaves a chief had, the greater his military and political power.

Soldier-slaves generally proved effective in the execution of various wars which were largely provoked by the desire of the nascent and imperial states of Ilorin, Ibadan, Ijaiye and Abeokuta to fill the vacuum provided by the demise of Old Oyo [1]. Ibadan therefore became the metropolis of an empire. The territorial extent of this empire kept expanding as Ibadan continued its military drive to add new areas of influence to her former possessions. Each of these wars of expansion produced a number of captives which were brought to Ibadan. The soldier-slaves, with the exception of the disastrous Kiriji war, always returned home victorious from all wars. They fought at Owiwi (1832) [8], Jabara (1835), Iperu (1836), Osogbo (1840), Ijaiye (18601862), Igbajo (1866-1867), and the sixteen years' war (1877-1893), which ended all wars in the Yoruba country $[2,21,25]$.

The wars, produced as many captives as possible. At the Ipetumodu and Osogbo wars, large number of Ilorin soldiers were taken as captives by the Ibadan soldiers. At the Ekiti and Ijesa countries, many people were taken as captives between 1854 and 1859. After these campaigns, it was reported that some 10,000 captives were brought into Ibadan [12, 24]. By 1870s, acquisition of slaves had reached its peak in Ibadan. Thus, slaveholding in Ibadan received its greatest boost from the highly successful wars fought by its army. Out of an estimated population of about 100,000 in 1877, the number of slaves far out-ran that of the freeborn and freedmen. The Ijesa and the Ekiti were predominant among such slaves. Salutations in the dialect of the Ijesa were common among the Oyo Yoruba who formed the majority group of the inhabitants of Ibadan [24]. One of the kings of the Ijesa in the 1880s, Owa Agunloye-bi-Oyinbo, was once a captive of the Ibadan, though he later escaped. It has however, been revealed that there was scarcely any man or woman in about the one thousand, four hundred and sixty Ijesa towns, that was not three or four times taken as a slave by the Ibadan [10, 24].

It is not surprising to see the Ibadan acquiring slaves in large numbers because the structure of the Yoruba society gave political, social and economic advantages to those large households that possessed numerous slaves. The more slaves an individual possessed, the greater the respect that was given to him. In military promotion, political appointments and fief-holding, the number of slaves and other omo-ogun possessed by an Ologun were considered. Slaves were used to measure the wealth of individuals in the society[6]. Most of the Ibadan war chiefs between 1856 and 1893, were at one time or the other private soldiers under the great Ibadan Ologun like Oluyedun, Oluyole, Elepo, Lajubu, Akinluyi and others. Among those private soldiers who rose due to their warring activities and acquisition of property in form of slaves, were Ibikunle, Ogunmola, Akere, Latosa, Abayomi, Ajayi, Jegede and a host of others. They all had large compounds where their numerous slaves and followers lived. Therefore, in this setting, slave-holding became the principal source of investment in which wealth and power reside. It was the chiefs' guarantor of social and political importance. 
Anna Hinderer, observing this socio-political structure concluded that 'slaves make a man great in this country'[15].

Having realised that possession of slaves was the shortest route to socio-political recognition, many of the Ologun were bent on acquiring as many as they could in the shortest period possible. They plundered many towns and cities, particularly the Ekiti and Ijesa territories, where they got a lot of slaves. According to Johnson, ... slave-raiding now became a trade to many who would get rich speedily, and hence those... who quickly spent their ill-gotten gains in debauchery and all excesses would band together for a raiding expedition...[25]

This insatiable appetite for acquisition of slaves coupled with the influx of other migrants and refugees into Ibadan led to a remarkable increase in the population of the city. It must be stated that it has been very difficult to really state the population of Ibadan in absolute terms. This becomes even more difficult when one considers the fact that one is talking of an age when all the indigenous inhabitants of Ibadan were non-literates. However, the population had been variously estimated by various travellers and writers, with some degree of accuracy, judging from the fact that there were not much differences in their accounts. Talbot [26]and Hinderer [15]in 1851 , put the population at 60,000 and 100,000 respectively. In 1856, it was estimated at 70,000 and between 1860 and 1890, it was put at 150,000 [19]. Another account also put the population at 150,000 in 1899[22].

These various accounts showed that in the period between 1830 and 1840s, there were few slaves in Ibadan. But from the 1850s, slaves were brought into the city in thousands. They were in every nook and cranny of the city and were as well engaged in one trade or the other in all sections of the economy by their masters and mistresses. In fact, the economy of Ibadan was dominated at the close of the nineteenth century by about one hundred ruling chieftaincy houses, which between them employed a large number of slaves in agricultural and trading activities [16]. Indeed, the influx of slaves like in the nineteenth century Sultanate of Zanzibar [3] created so much fear of the possibility of a slave insurrection in the minds of the Ibadan authorities, that it was decreed in the 'name of Oke-badan' in 1859, that the Ibadan should desist from going to war for sometimes. It was said that there were too many strange people in the town and to continue to swell the population through the acquisition of new captives might bring destruction on the town [26, 24].

In the attempt to enforce this decree, Balogun Ibikunle had to divert the minds of Ibadan Ologun and their soldier-slaves from war in 1859, by making them build the third town wall. The wall, called Odi Ibikunle, was named after the Balogun because he suggested, planned and supervised its erection [25]. Meanwhile, the decree was not to last for more than a few months before the Ibadan went back to war in 1860 with the Ijaiye and until 1893, Ibadan in particular and the Yoruba country in general knew no peace. This third wall also was partly built to protect the ever increasing population of Ibadan. However, the dreaded population growth turned out to provide the stimuli for the expanding economy of Ibadan in our period. Among the migrants who further greased the engine of growth in Ibadan by contributing their own little quota, were craftsmen, farmers, diviners, musicians, blacksmiths and ambitious soldiers who could no longer cope with the inhibiting and stifling traditional set up of the older Yoruba cities. Therefore, with the abundance of opportunities and security which Ibadan provided as a city located in a strategic place; where most of the trading opportunities in the Yoruba country could be tapped; and as a city that could boast of many distinguished warriors who could successfully defend the town, these people were able to settle down and establish their various occupations [13].

The numerous slaves that were brought into Ibadan and who had swollen the population of the city were used for various economic pursuits. They were important in the exchange for arms and ammunition for the prosecution of wars. That is, they were used to finance the wars by being sold in exchange for weapons. This has been the reason why some writers and media organisations $[11,15,28,29,30]$ particularly in Europe, concluded that the wars of the nineteenth century Yorubaland were fought principally to acquire slaves for the maintenance of social status and exchange for weapons and other finished goods from European traders at the coast. But with the development of African historiography, this erroneous impression has always been debunked by modern African historiographers.

The African historians submit that the issues involved in the nineteenth century Yoruba wars were both economic and political. It was economic because those involved wanted more captives and as long as the Whiteman's weapons were able to enter the interior of Yoruba country, the wars would continue; and as long as the wars continued, there would always be captives of war to maintain social status of the Ologun and other civil chiefs. It was also political as far as the question of balance of power in the Yoruba country was concerned particularly after the collapse of the Old Oyo Empire. Indeed, it should not be forgotten that in the early kingdoms of the Yoruba including the Old Oyo, slavery and slave trade had existed and there had been wars of diverse motives. Therefore, wars, though destructive, irrespective of where they were fought, had always been and will always be fought for political and economic reasons.

Furthermore, the notion that the Yoruba wars were fought without serious thoughts is baseless because there were always internal and international attempts to resolve issues of war. It was only after the failure of diplomatic attempts at peaceful settlement, that wars were declared. According to R. S. Smith, 
...warfare was undertaken by the Yoruba with deliberations. Only after lengthy discussion in the councils of the kingdom that the army moved out to the vicinity of the enemy [27].

For instance, both the Alaafin of Oyo and the authorities of Ibadan tried to avoid the Ijaiye war (1860-1862), but the obstinacy of the strongman of Ijaiye, Kurunmi, made peace difficult. Johnson commenting on this writes:

all hopes of a pacific settlement were now given up, for private messages, advices and remonstrances were without number to the Are (Kurunmi), but for all this (he) remained unyielding to the king (Alafin) and defiant to Ibadan [25].

Equally, diplomatic attempts were made by both the Egba and the Ibadan to avert the wars of the trade routes. And precisely, by July 12, 1877[25],representatives of both parties had been on the conference table at Ibadan to amicably discuss their annoyance. Although the uncompromising attitudes of the two parties involved destroyed this attempt at peaceful settlement. The point is that had the wars been conceived purely for economic reasons, there would have been little need for such attempt at peaceful settlement. Therefore, what can be said in this connection is that there were always the appetite for taking captives who could be profitably disposed of and this probably prolonged particular campaign and may also have prolonged the general state of warfare among the Yoruba states in the nineteenth century. In other words, captives were just by-products of the various wars and once they were got and sold profitably, the urge to continue with the war to produce more captives was to be expected.

Moreover, there were instances when captives of wars were sent back to their various towns. Also captives who had been kept as political prisoners were sometimes exchanged. In addition, there were times when captives were not taken at all even when there were opportunities to acquire them. There were examples to support these claims and one that readily comes to mind was the release of the Ijebu taken as captives by the Ibadan after the war of the trade routes. Are Latosa returned all the Ijebu taken as prisoners of war unsolicited and protested his unwillingness to fight with the Ijebu [28]. Another instance could be drawn from the Ikirun or Jalumi war of 1878. In this battle, Balogun Ajayi Ogboriefon defeated the Ijesa at Ikirun and instead of taking them as captives, he commanded Ibadan soldiers with a charge that 'let no one stay for booty or captives, all prisoners must be slain at once' $[2,21,25]$. Although this act may be barbaric and savagery, it has vindicated the point that wars were not fought primarily to capture slaves.

\section{The importance of the slaves in Wars and Diplomacy}

The importance of the slaves in the foregoing analysis is the fact that they were extensively used to finance the wars. Some of them were sold overseas in exchange for weapons of war and like it has been pointed out, some were drafted into the various private armies. Generally, slaves became viable articles of trade, presents, tributes and diplomatic concessions, that several hundreds changed hands in the course of the century. Slaves were bartered for short and long parallel muskets, American Snider (breach loading rifles) and Danish firearms. The powder was mainly got from Boston, U. S. A., and was a coarse substance with a high charcoal content [2].The ammunition consisted of bullets and bar-iron of varying sizes, cast and cut by local blacksmiths, who were also sword-makers. The use of firearms not only influenced decisions on the battle field, but also, and perhaps to a greater extent, alters the political course of events at home. Therefore, since the weapons and powder were all imported, slaves were sold to the coast in increasing numbers to ensure supplies.

The people of Lagos, Badagry, the Ijebu and the Egba served as the middlemen in the business of human trade. They would buy the slaves from the interior markets including Ibadan and marshalled them, men, women and children in caravans for the march to the European traders at the coast. From the coast, the arms would travel inland through the middlemen [13].Prices of the slaves varied from time to time, depending largely on the volume of demand relative to supply. In our period, the average price by an African slave-dealer for a male slave varied between 40,000 and 60,000 cowries, which, according to the average rate of exchange was equivalent to between $£ 3$ and $£ 8$ respectively. Generally, the sick and injured slaves were lumped with the helpless women and children; and sold off cheaply as 'refuse'[2]. However, between July 1862 and the end of 1864 , arms and powder which the slaves were bartered for were estimated at $£ 23,000$ and most of these were transmitted to Ibadan through the Ijebu middlemen at Ikorodu [2]. The acquisition of large quantities of arms and ammunition from the coast placed Ibadan in an advantageous position over many other Yoruba states and consequently, it virtually became impossible for the Yoruba to return to a more peaceful way of life.

Furthermore, it should be pointed out that the slaves were not indiscriminately exchanged for weapons. Screening of all captives was done in order to determine how each should be treated. The able bodied and the blacksmiths among the slaves were highly valued by the Ologun, for their skill both at the battlefield, and in the production of agricultural and war implements. In the nineteenth century Ibadan, most of the important households had their own smithies and therefore, it is not surprising that today, there are more blacksmiths in the older parts of the town, where the more important Ologun had their compounds [7]. Besides the blacksmiths, there were the soldier-slaves, whose services as earlier stated were important and were not to be disposed either 
for ammunitions or other European manufactured goods, as long as they were still in active service of their masters [9]. The slaves were very important in the prosecution of wars and could determine the course of any war whenever they wished to, depending on their treatment. For example, their importance was felt at Osiele, during the war of the trade routes with the Egba. The Ibadan soldier-slaves realising that a great number of them were being killed, an act they attributed to the negligence on the part of the war-chiefs, withdrew from the battle, leaving Are Latosa (Head-Chief, 1871-1885), and his war-chiefs. The 'Are' had to retreat when the remnants of his army could not contain the Egba onslaught. In fact, the 'Are' could have been captured by the Egba troops, but for Sanusi, his son and Idagana, one of his principal slaves, who suddenly charged at the attacking army [25].

Another example was during the Jalumi war in which the Osi Balogun, Ilori, the great Ogunmola's son, had offended his principal soldier-slaves by inflicting facial marks on them as punishment, despite the representation from other soldier-slaves to make him see reason [21] and temper justice with mercy. Thus when the battle was at its peak, the soldier-slaves deserted him, though the usual practice was for the soldier-slaves to surround the Ologun who led them to battle [25]. Consequently, he was captured by the Ilorin forces and eventually put to death. Such was the importance of the soldiers-slaves in the determination of the course of wars and the strength of the Ologun.

Slaves were also important in international relations and diplomacy. Whenever there was the need to be at peace with its neighbours, particularly the Ijebu, slaves were used as diplomatic gifts. In some cases, this was done to avert wars and to keep some important trade routes opened. There were also cases when slaves were given as diplomatic gifts to secure allies in the event of war. During the war of the trade routes in 1877-78, the Ibadan sent presents of twelve slaves to the Ijebu war camp and at the same time, sent seventy slaves with valuable beads to the Awujale [28].This was done partly by Are Latosa to assure the Ijebu that he was unwilling to fight them and to plead with them to open the trade route to the coast. It was also to bring the Ijebu to fight on the side of the Ibadan at the Kiriji war which had just commenced. Though the Awujale refused to accept the 'Kola of Peace', the diplomacy paid off, as the King was expelled by the Ijebu chiefs and the trade route was opened to the coast [25]. Similarly, before the Ijaiye war, Alafin Adelu, realising he could not risk going to war with the powerful Are, resorted to diplomacy to muster the support of Ibadan. He therefore, sent to Ibadan chiefs forty slaves, beads and other valuables to show he had declared war against the Ijaiye. ${ }^{48}$ Such were the importance of slaves in all campaigns the Ibadan were involved in during the period of study.

\section{Conclusion}

This has been the story of the military state of pre-colonial Ibadan. Ibadan rose as a war camp from the ruins of the Egba villages to become an important town where the inhabitants developed the propensity for militarism. The military means was developed in such a way that military campaigns became the order of the day in Ibadan. Through the acquisition of slaves that were easily drafted into the Ibadan army, the city became the defender of Yorubaland, particularly against the Fulani who were almost overrunning Yoruba country from the north. A fearful military state that developed from the sweats of its soldier-slaves. Ibadan was the home of great pre-colonial military leaders like, Oluyedun, Oluyole, Lajubu, Akintuyi, Ibikunle, Ogunmola, Akere, Latosa, Abayomi, Ajayi, Jegede and a host of others who except from the disastrous Kiriji war were always returning home victorious from all wars. Some of such wars were the Owiwi War(1832), Jabara War (1835), Iperu War (1836), Oshogbo War (1840), Ijaiye War (1860-62), Igbajo War (!866-67), and the Sixteen years War (1877-1893) which ended all wars in Yorubaland and coincided with the establishment of British Colonial Rule in the hinterland of Yoruba country.

\section{Endnotes}

[1] Afolayan, F. (1986) 'Warfare and Slavery in the nineteenth century Yorubaland', a paper read at the National Conference on the centenary of the Kiriji/Ekitiparapo Peace Treaty, held at the University of Ife (now Obafemi Awolowo University), Nigeria, 21 st 26th, September, 1986

[2] Ajayi, J.F.A and R. S. Smith, (1964) Yoruba Warfare in the nineteenth century, (London)

[3] Akinola G.A (1971) 'Slavery and Slave Revolts in the Sultanate of Zanzibar in the Nineteenth entury', J.H.S.N., 6, 2, June, 1972, 222-224.

[4] Akintoye, S. A. (1971) Revolution and Power politics in Yorubaland 1840-1893; Ibadan Expansion and the Rise of Ekiti-Parapo, (London: Longman)

[5] Akintoye, S. A. (1980) The Economic Foundations of Ibadan's Power in the Nineteenth Century" in I.A Akinjogbin and S.O Osoba, (ed.) Topics on Nigerian Economic and Social History, (Ile-Ife: University of Ile-ife Press)

[6] Awe,B.A (1964) 'The Rise of Ibadan as a Yoruba Power in the Nineteenth Century', D. Phil., (Oxford)

[7] Ayorinde, J. A. Chief (70+), Ekarun Olubadan. Interviewed at his residence, NW6/105, Ekotedo, Ibadan

[8] Biobaku, S.O. (1964) The Egba and their Neighbours1842-1872, (Oxford: Clarendon Press)

[9] Bioku T. B (80+), Mogaji Bioku. Interviewed at his residence in Oranyan, Ibadan.

[10] C. O. 147/48, Statement made by His Majesty, King Owa Agunloye-bi-Oyinbo, January 12, 1862, cited in Rowe to Kimberley, March 14, 1882

[11] Elgee, C. H., (1914) The Evolution of Ibadan, (Lagos)

[12] F. O. 84/976, Campbell to Clarendon, December 7, 1855 
[13] Falola, T. (1984) The Political Economy of an African State: Ibadan, 1890-1900, (Ife, 1984)

[14] Fourchard, L. (2008) "Urban Slums Reports: The case of Ibadan, Nigeria", IFRA, 2008, 2

[15] Hinderer, A. (1873) Seventeen Years in Yoruba Country (London)

[16] Hopkins, A. G. (1966) 'Economic Aspects of Political Movements in Nigeria and Gold Coast, 1918-1939', Journal of African History, JAH, 7, 140

[17] Ibadan Mementoes “Oba Adeyemo's Noble Past, Glorious Present and Progressive Future X-rayed; Historical Perspective on Ibadanland" (Ibara, 1995)

[18] Iwe Irohin Yoruba, June, 1861.

[19] Jenkins, G. (1965) 'Politics in Ibadan', Ph.D. Thesis, North-western University, (Illinois)

[20] Lagos Weekly Times, May 24, 1890 and 1890 and

[21] Morgan, Kemi (1900)Akinyele's Outline History of Ibadan, translated, revised and enlarged by vol. II (Ibadan: Caxton)

[22] NAI: 'Lagos Annual Reports', 1899, 11

[23] Omosini, O.O (1991) "Evolution of African Historiography: An Overview", Inaugural Lecture, series 97, Obafemi Awolowo University, Ile-Ife.

[24] Oroge, E. A. (1971) 'The Institution of Slavery in Yorubaland with reference to the nineteenth century', Ph.D Thesis, Birmingham

[25] Samuel Jonson, (1921 reprinted 2001) The History of the Yorubas: From the earliest times to the beginning of the British Protectorate, (Ibadan; CSS Limited)

[26] Smith, R. S

[27] Talbot, P. A. (1926) The Peoples of Southern Nigeria (London) Vol. I, 298

[28] The Lagos Times, March 14, 1883

[29] The Lagos Times, December 27, 1882

[30] The Lagos Times, February 7, 1891

[31] Watson, Ruth (1999) "Ibadan-a model of historical facts': militarism and civic culture in a Yoruba city" Urban History, 26, 1 